\title{
Aggressive Mature Natural Killer Cell Neoplasms: From EBV-Infection to Disease Etiopathogeny
}

\section{Margarida Lima*}

Laboratory of Cytometry, Department of Hematology, Hospital de Santo António (HSA), Centro Hospitalar do Porto (CHP), Multidisciplinary Unit for Biomedical Investigation (UMIB/ICBAS/UP), Porto, Portugal

\begin{abstract}
Mature Natural Killer (NK) cell neoplasms are rare tumors with higher prevalence in Asia, Central and South America, which are related to Epstein Barr Virus (EBV) infection. Nature killer /T cell lymphoma, nasal type, presents as a localized or generalized destructive tumor, affecting the nose, the upper aero digestive tract or any organ or tissue, whereas aggressive NK-cell leukemia manifests as a systemic disease that preferentially affects the bone marrow, the spleen and the liver, and rapidly evolve to multiorgan failure resulting in death. Both NK-cell neoplasms arise as a consequence of the inability of the immune system to control EBV infection and of the transforming potential of multiple EBV gene products. Chronic active EBV infection and EBV-related lymphoproliferative disorders of NK-cells are predisposing conditions. The tumor NK-cells do express an EBV infection type II latency pattern, specific EBV-encoded latent membrane proteins and early region EBV RNAs being detected on lymphoma cells. The EBV encoded proteins and non-coding EBV RNAs and micro-RNAs expressed on the infected cells are involved in immune deregulation and play a crucial role in cell transformation and oncogenesis. This review addresses the mechanisms used by EBV to infect the cells and to evade the immune-surveillance as well as to induce cell survival and transformation, and characterizes the spectrum of the clinical manifestations associated with chronic EBV-infection and related T-and NK-lymphoproliferative disorders. Improving the knowledge in this subject will help to develop new therapeutic approaches for chronic EBV-infection and even prevention strategies for the aggressive NK-cell malignancies.
\end{abstract}

Keywords: NK-cell neoplasms; NK/T-cell lymphoma; Nasal-type; Aggressive NK-cell leukemia; Epstein Barr Virus; Chronic active EBVinfection; Viral-induced cell transformation

\section{List of Abbreviations}

AIDS: Acquired Immunodeficiency Syndrome; AIP4: Atrophin1-Interacting Protein 4 (Nedd4-Like E3 Ubiquitin Ligase); ANKCL: Aggressive NK-Cell Leukemia; BCL2: B-Cell CLL/Lymphoma Protein Type 2; BCL6: B-Cell CLL/Lymphoma Protein Type 6; BCR: B-Cell Receptor; BM: Bone Marrow; BRAM: BMP Receptor Associated Molecule; CAEBV: Chronic Active EBV Disease; CBF1: Centromere Binding Factor 1; CLPD-NK: Chronic Lymphoproliferative Disorders of NK-Cells; CNKCL: Chronic NK-Cell Lymphocytosis; CTL: Cytotoxic T-Lymphocytes; Dcr3: Decoy Receptor Type 3; DNA-PK: DNA-Protein Kinases Catalytic Subunit; EBER: Early Region Epstein Barr Virus RNA; EBNA: Epstein Barr Virus Encoded Nuclear Antigens; EBNA-LP: Epstein Barr Virus Nuclear Antigens Leader Protein; EBV: Epstein-Barr Virus; EBV-AN: Epstein Barr Virus Encoded Alkaline Nuclease; EBVEA: Epstein Barr Virus Encoded Early Antigens; EBV-HLH: Epstein Barr Virus-Associated Hemophagocytic Lymphohistiocytosis; EBVLPD: Epstein Barr Virus-Associated Lymphoproliferative Disorders; EBV-MA: Epstein Barr Virus Encoded Membrane Antigen; EBV-VCA: Epstein Barr Virus Encoded Viral Capsid Antigen; Fasl: Fas Ligand; FLIP: FLICE Inhibitor Protein; HAUSP: Herpes Virus-Associated Ubiquitin-Specific Protease; HAX-1: HCLS1-Associated Protein X-1; HHV: Human Herpes Viruses; HLA: Human Leukocyte Antigens; HLH: EBV-Associated Hemophagocytic Lymphohistiocytosis; HMB: Hypersensitivity To Mosquito Bites; HS: Hemophagocytic Syndrome; HV: Hydroa Vacciniforme; ICAM-1: Intercellular Adhesion Molecule -1; IFN: Interferon; IFN-Gamma: Interferon-Gamma; IGF-1: Insulin Growth Factor Type 1; IL: Interleukin; IL-10: Interleukin 10; IL-1A: Interleukin 1 Alpha; IL-2: Interleukin 2; IL-6: Interleukin 6; IL-9: Interleukin 9; IRF-3: Interferon Regulatory Transcription Factor 3; ITAC: IFN-Inducible T-Cell Attracting Chemokine (CXCL11); ITAM: Immunoreceptor Tyrosine-Based Activation Motif; JAK: Janus Kinase;
JNK: C-Jun N-Terminal Kinases; KLR: C-Type Lectin-Like Receptors; KSHV: Kaposi's Sarcoma Associated Herpes Virus; LANA1: LatencyAssociated Nuclear Antigen Type 1 (From KSHV); Lck: Member Of The Src-Family Tyrosine Kinase; LFA: Leukocyte Function Adhesion Molecule; LMP: Epstein Barr Virus-Encoded Latent Membrane Protein; LN: Lymph Nodes; LPD: Lymphoproliferative Disorders; Lyn: Member Of The Src-Family Tyrosine Kinase; MAPK: MitogenActivated Protein Kinase; Mi-Rnas: Micro Rnas; NEDD4: Neural Precursor Cell Expressed Developmentally Down-Regulated Protein 4 (E3 Ubiquitin Ligase); Nfkb: Nuclear Factor $\kappa \tau \mathrm{B}$; NK: Natural Killer; NKTCL: NK/T Cell Lymphoma; P53: Tumor Protein P53; PCR: Polymerase Chain Reaction; PI3: Phosphoinositide 3-Kinase; PI9: Protease Inhibitors 9 (Also Known As SERPIN9); PKB: Protein Kinase B (Also Known As Akt); PKC: Protein Kinase C; PKR: Protein Kinase RNA-Dependent; PUMA: P53 Up-Regulated Modulator Of Apoptosis; RAF: Rapidly Accelerated Fibrosarcoma Kinases; RAG: Recombination Activation Genes; RBP-2N: Recombination Signal Sequence-Binding Protein 2N; RBP-J: Recombining Binding Protein Suppressor Of Hairless; RIG-I: Retinoic-Acid Inducible Gene I; SMBA: Severe Mosquito Bite Allergy; SERPIN9: Serine Protease Inhibitors 9 (Also Known As PI9); Src: Member Of The Src-Family Tyrosine Kinase; Src: Short For "Sarcoma" (Tyrosine Kinase); STAT: Signal Transducers

*Corresponding author: Margarida Lima, Laboratory of Cytometry, Department of Hematology, Hospital de Santo António, Centro Hospitalar do Porto, Rua D. Manuel II, s/n 4099-001 Porto, Portugal, Tel: + 351-22-2077500; Fax: +351-22600480; E-mail: mmc.lima@clix.pt : margaridalima@chporto.min-saude.pt

Received November 25, 2013; Accepted December 26, 2013; Published December 31, 2013

Citation: Lima M (2013) Aggressive Mature Natural Killer Cell Neoplasms: From Ebv-Infection to Disease Etiopathogeny. J Blood Disorders Transf 5: 193. doi: $10.4172 / 2155-9864.1000193$

Copyright: (c) 2013 Lima M. This is an open-access article distributed under the terms of the Creative Commons Attribution License, which permits unrestricted use, distribution, and reproduction in any medium, provided the original author and source are credited. 
And Activators Of Transcription; Syk: Spleen Tyrosine Kinase; TAP: Transporter Associated With Antigen Processing; TCR: T Cell Receptor; Th: T Helper; Th1: T Helper Type 1; Th2: T Helper Type 2; TLR3: Toll-Like Receptor Type 3; TNF: Tumor Necrosis Factor; TNFR: Tumor Necrosis Factor Receptor; TRADD: Tumor Necrosis Factor Receptor Type 1-Associated DEATH Domain Protein; TRAF: TNF Receptor Associated Factor; USP: Ubiquitin-Specific Protease; VCA: Viral Capside Antigens; Vil-10: Viral Homologue Of Interleukin 10; WHO: World Health Organization; ZAP-70: Zeta-Chain-Associated Protein Kinase 70

\section{Introduction}

The Epstein Barr Virus (EBV) is a ubiquitous Human Herpes Virus (HHV) that infects more than $90 \%$ of the world's population, leading to a lifelong infection. Disease occurs when the immune system fails to control the virus and a chronic active infection and/or EBV-related malignancies develop $[1,2]$.

Natural Killer (NK) cell neoplasms are rare diseases categorized by the World Health Organization (WHO) classification of tumors of hematopoietic and lymphoid tissues as extranodal NK/T Cell Lymphomas, Nasal Type (NKTCL), Aggressive NK-Cell Leukemia (ANKCL) and as a provisional entity, Chronic Lymphoproliferative Disorders of NK-Cells (CLPD-NK) [1-23]. They are relatively frequent in Central and South American and Eastern countries, although very uncommon in North America and Europe, and in NKTCL, as in ANKCL, evidence for latent EBV infection in lymphoma cells is a consistent finding [3-19,24-27].

There are two variants of NKTCL, the nasal and extranasal forms. The nasal form manifests as a localized disease affecting the upper aero digestive trait, although dissemination may occur in advanced disease stages $[3,12,16,28]$. Patients with the extranasal variant frequently have multiple organs and tissues involved at the time of the diagnosis and the disease usually has more adverse clinical features $[3,12,16,28]$. Bone Marrow (BM) involvement at the diagnosis is uncommon and the hemophagocytic syndrome (HS) is relatively frequent, especially in advanced disease $[6,29,30]$. Some cases of NKTCL presenting in the lymph nodes (LN) were also described [31-36].

Aggressive NK-cell leukemia is a very rare disease with a fulminant clinical course [4,37-41]. Patients usually present with systemic symptoms, BM infiltration, pancytopenia, hepatosplenomegaly and abnormal liver function, and frequently develop hemophagocytosis, multiorgan failure and disseminated intravascular coagulation [42-48].

Patients with CLPD-NK presents with a persistent increase in circulating NK cells often associated with other conditions such as neutropenia, anemia and vasculitis [23]. The disease is clinically indolent and since it is difficult to determine clonality for NK cells, in most cases it is uncertain whether the condition is reactive or neoplastic [23].

Previous studies revealed a strong association between NK-cell neoplasms and EBV infection throughout the world; for nasal NKTCL, EBV has been nearly always positive, irrespective of the ethnic origin of the patient, whereas for extranasal NKTCL, EBV association is stronger in Oriental patients than in Caucasians [38,49]. EBV proteins and RNAs are detected in lymphoma cells in the vast majority of the NKcell tumors, using immunohistochemistry and in situ hybridization, respectively and the analysis of the terminal repeat region of the EBV genome shows that the virus is in a clonal episomal form, providing an indirect evidence for the clonal nature of the NK-cell proliferation and suggesting that the EBV plays a role in oncogenesis $[38,49,50]$. In contrast, evidence of EBV infection is rarely found in CLPD-NK, at least in western countries [23]

We review the etiopathogeny and the predisposing conditions of the aggressive NK cell neoplasms (NKTCL and ANKCL) with emphasis on the virological and immunological features of the EBV infection, including the mechanisms used by EBV to evade the immune surveillance and the transforming potential of specific EBV gene products. Increasing our understanding in this matter promise for the development of more rational treatment of the EBV-infection and could contribute to more effective approach of the EBV-related malignancies.

\section{Etiopathogeny of the NK-Cell Neoplasms}

The EBV has two subtypes which differ from each other at the BYRF1, the viral gene that codifies for the EBV nuclear antigen type 2 (EBNA-2) [51]. Type $1 \mathrm{EBV}$ is dominant in the Western hemisphere and Southeast Asia and type $2 \mathrm{EBV}$ predominates in lymphomas of immunocompromised patients whereas both are equally prevalent in Africa [52-54].

\section{Primary EBV infection}

Primary EBV infection is usually asymptomatic in childhood; but in adults, it frequently manifests as an acute infectious mononucleosis syndrome [55]. Initial EBV infection probably occurs in the tonsils, where the virus infects the epithelial cells and B-cells, using different mechanisms: to enter epithelial cells, the viral protein BMRF-2 interacts with cellular beta-1 integrins, whereas to enter B-cells, the viral glycoprotein gp350 binds to the C3d complement receptor, CD21 [1]. T-cells and NK-cells can also be secondarily infected, probably by passive acquisition of the $\mathrm{CD} 21$ molecule due to membrane fragment exchange during the cytotoxic cell-target cell interactions [56].

\section{EBV life cycle}

Once the EBV enters into the host cell, its genome is transported to the nucleus, where linear EBV replication by viral DNA polymerases begins, resulting in the production of new viruses during the lytic phase of the viral life cycle. EBV gene products then activate B-cells resulting in B-cell proliferation. Activated B-cells may continue to undergo lytic replication or, if EBV shuts down some of the genes, latency occurs [57]

Latency is a chronic infection without active viral production, during which EBV persists inside B-cells and possibly also in epithelial cells; at that phase, EBV genomes exist mainly as episomes, whose replication occurs via host DNA polymerase. Occasionally, the EBV reactivates inside infected $B$ cells, thereby producing new viruses that infect other cells [57].

\section{EBV latency patterns}

During the latent phase, where infected cells maintain viral DNA as episomes, there is a variable expression of six EBV nuclear antigens (EBNA)-EBNA-1, EBNA-2, EBNA-3A, EBNA-3B, EBNA-3C, and EBNA-LP-, two EBV latent membrane proteins (LMP)-LMP-1 and LMP-2, with two isoforms, LMP-2A and LMP-2B-, and two EBVencoded RNAs (EBER)-EBER-1 and EBER-2 [57].

Characterization of gene expression patterns in EBV-infected cell lines allowed for identifying at least three latency programs (type I, II and III) (Table 1). Only EBNA-1 is expressed in the type I program, which is seen in Burkitt's lymphoma; EBNA-1 and LMP$1 / 2$ are expressed in the type II program, observed in nasopharyngeal carcinoma and Hodgkin's lymphoma; the type III program, in which 


\begin{tabular}{|c|c|c|c|c|c|c|c|}
\hline EBV genes & & BKRF1 & BYRF1 & BLF-BERF $(1,2,3 / 4)$ & BNLF1 & BNLF2 & BCRF1 \\
\hline EBV-protein & & EBNA-1 & EBNA-2 & EBNA-3 (A,B,C) & LMP-1 & LMP-2 (A,B) & $\begin{array}{l}\text { Not translated } \\
\text { EBER-1,2 }\end{array}$ \\
\hline \multicolumn{2}{|c|}{ Immunogenic properties * } & $-/+$ & + & ++ & $-/+$ & $-/+$ & - \\
\hline \multirow{2}{*}{ EBV infection phase } & Lytic phase ** & + & + & + & - & - & - \\
\hline & Latency phase & + & $-/+$ & $-/+$ & $-/+$ & $-/+$ & + \\
\hline \multirow{4}{*}{ EBV latency patterns } & Type 1 (Burkitt's lymphoma) & + & - & - & - & - & + \\
\hline & $\begin{array}{l}\text { Type } 2 \text { (nasopharyngeal carcinoma, Hodgkin's lymphoma } \\
\text { and NK/T-cell neoplasms) }\end{array}$ & + & - & - & + & + & + \\
\hline & $\begin{array}{l}\text { Type } 3 \text { (Infectious mononucleosis, AIDS associated lympho- } \\
\text { mas, post-transplant B-cell LPD) }\end{array}$ & + & + & + & + & + & + \\
\hline & Others (healthy carriers) & + & - & - & - & + & + \\
\hline
\end{tabular}

AIDS: Acquired Immunodeficiency Syndrome; CTL: Cytotoxic T Cells; EBV: Epstein Barr virus; EBNA: EBV Nuclear Antigens; LMP: EBV Latent Membrane Proteins; EBER: Early Region Epstein Barr Virus RNA; LPD: Lympho Proliferative Disorder; NFkB: Nuclear Factor kappa B; TNFR: Tumor Necrosis Factor Receptor; PKC: Protein Kinase C. ${ }^{*}$ Immunogenic properties for the generation of cytotoxic T cells; ${ }^{* *}$ Other EBV antigens expressed during the lytic phase are the EBV-EA (early antigens), the EBV-MA (membrane antigen), the EBV-VCA (viral capsid antigen) and the EBV-AN (alkaline nuclease)

Table 1: Expression of EBV genes and proteins during the viral cycle and viral latency phase patterns associated with EBV related diseases [1,2]

all of the latency gene products are expressed, is detected during acute infectious mononucleosis, as well as in EBV related post-transplant B-cell LPD and other LPD in immunocompromised individuals [57].

Similarly to that occurring in Hodgkin's lymphoma, tumor NKcells are believed to be in latency II, and viral proteins expressed are limited to EBNA-1, LMP-1, and LMP-2; however, LMP-2 has only been demonstrated at the transcriptional level and LMP-1 expression is variable [58].

\section{Anti-EBV immune response}

Innate and adaptive immune responses occurring in primary EBV infection involve both cellular and humoral mechanisms [59]. EBVinfected B-cells are first controlled by NK-cells, and later by EBV-specific cytotoxic T lymphocytes (CTL). Among the EBV latency proteins, the EBNA-3 is the most immunogenic for the generation of CTL.

Distinct patterns of antibody response have been identified during primary infection, latent infection of healthy carriers, viral reactivation, and in various EBV-associated diseases, which include IgG and IgM directed against EBV early antigens (EA) -D and -R (encoded by BHRF1), EBV viral capsid antigens (VCA) and EBNA-1\&2.

\section{EBV-specific assays}

EBV-specific antibody tests: Anti-EBV antibodies are usually detected by solid-phase enzyme immunoassay (ELISA) and the antibody profile distinguishes acute primary, convalescent, and past infections [60]. Acute primary EBV infection is characterized by the presence of anti-VCA IgM antibodies. During convalescence (from the third week to the third month after the onset of illness) the anti-VCA IgM antibodies decrease, while anti-VCA IgG antibodies rise. Between the third and sixth months, anti-VCA IgM antibodies disappear, and anti-EBNA-1 IgG antibodies become detectable. Both anti-VCA and anti-EBNA-1 IgG antibodies persist for life.

Viral detection and quantification: In situ hybridization to detect EBERs, often complemented with LMP-1 immunostaining, is the gold standard for detecting EBV in tissues; in turn, polymerase chain reaction (PCR) is the technique of choice for detecting and quantifying EBV in body fluids $[61,62]$. Quantitative PCR assays in whole blood samples or in plasma are routinely used to monitor EBV loads in patients that are at risk for EBV-related diseases, such as post-transplant LPD, as well as for evaluating the effects of anti-EBV therapy [63-65]. EBV-copy numbers are usually 10- to 100- folds lower in plasma than those in whole-blood. The management of EBV infection after transplant is usually based on the increase in viral load over time, assuming that when the number of viral copies increases, active viral replication is probably occurring. Viral loads higher than 4000 copies/ $\mathrm{ml}$ of whole blood or rising levels on the number of viral copies usually prompt a reduction of the immunosuppression and initiation of anti-viral treatment, whose goal is to drive the blood viral load below the level of detection, or at least to less than 1000 copies/ml [66].

\section{Mechanism used by EBV to Evade the Immune System}

Although the immune system usually controls infection, it is not able to eliminate the virus, most adults having a chronic latent and asymptomatic EBV infection. The mechanisms by which the viruses escape from immune surveillance and survive are complex and include reduction of the immunogenicity the infected cells, inhibition of the cytotoxic response, and modulation of the apoptotic and cytokine signals, among others [58,67-81].

\section{Reducing the immunogenicity of the infected cells}

Active immune evasion mechanisms that reduce the immunogenicity of infected cells are of major importance during both the lytic and the latency phases of the viral cycle.

Down-regulating HLA class I expression: A strategy used by the EBV to escape the immune system is to down-regulate the expression of Human Leukocyte Antigens (HLA) class I antigens, including HLA-A and $-B$ types, and HLA-E, on the surface of the infected cells, thereby impeding presentation of viral antigens and CTL recognition. This effect is at least in part mediated by the virally encoded $G$ proteincoupled receptor BILF1, expressed early in the viral lytic cycle [67].

Blocking antigen processing: The EBV gene BNLF2a, which encodes for an inhibitor of the transporter associated with antigen processing (TAP), is expressed early upon infection, reducing antigen presentation and recognition of the EBV-infected B-cells by specific CTL [68]. In addition, the EBNA-1, encoded by the BKRF1 gene and expressed in most EBV-carrying cells, is poorly immunogenic, as it inhibits its own processing through the ubiquitin-proteasome system and the subsequent association of the derived peptides with the HLAclass I molecules [69].

Losing EBV-induced immunogenic proteins: A possible way for infected cells to evade the immune response during latency is to lower the expression of the most immunogenic EBV antigens. EBNA-3A, -3B and $-3 \mathrm{C}$ are usually the dominant targets for $\mathrm{EBV}$-specific CTL responses, 
but examples of responses directed against other EBNA or the LMP have also been described [70]. Thus, the fact that EBV-infected tumor NK-cells do express only EBNA-1 and LMP-1/2 (type II latency pattern) may enable them to evade host CTL [58].

\section{Producing immunosuppressive cytokines}

Herpes viruses are able to produce cytokine homologues, some of which have immunosuppressive functions [71]. For instance, the EBV gene BCRF1 encodes for a viral homolog of interleukin (IL)-10 (vIL10), which impairs NK cell mediated killing of infected cells, interferes with CD4+ T-cell activity, and modulates cytokine responses [68].

\section{Inhibiting the cytotoxic response}

Neutralizing the cytotoxic response by soluble FasL and decoy receptors for FasL: Previous studies suggested that lymphoma cells are able to interfere with the Fas/Fas ligand (FasL) pathway, thereby escaping to apoptosis. In accordance, patients with NKTCL and ANKCL have been shown to have high levels of FasL in the serum, which may neutralize the Fas receptor expressing on CTL [72-74]. In addition, EBV-infected tumor cells, including NK-cell neoplasms, are able to produce decoy receptors for FasL, such DcR3 (decoy receptor type 3), which binds to FasL and inhibits FasL-induced apoptosis [75].

Expressing ectopic proteins that are able to suppress the cytotoxic response: The PCDH15C gene codifies for the secreted isoform of the protocadherin 15 , which, as other cadherins, is normally not expressed in hematopoietic cells [76]. Ectopic expression of $\mathrm{PCH} 15 \mathrm{C}$ was described on tumor-derived NK-cell lines, as well as in tissue biopsies from patients with NKTCL [77]. The fact that cadherins are able to inhibit NK-cell mediated cytotoxicity by acting as ligands for inhibitory killer cell lectin type receptors (KLR), would suggest that this mechanism used by the NKtumor cells to escape immunosurveillance [78].

Producing granzyme inhibitors: The main pathway used by NK-cells and CTL to kill their targets involves the release of the cytotoxic molecules contained in their granules, including perforin and granzymes. In particular, granzyme B acts by activating caspase-3, leading to apoptosis of the target cells. Cytotoxic cells have mechanisms to resist to their own cytotoxic effects [79]. Granzyme B-specific serine protease inhibitors, such as SERPINB9 (serine protease inhibitors 9, also known as PI9, protease inhibitors 9) protect effector cells from their own cytotoxic activity and may participate in tumor escape [80]. Unexpectedly, loss of expression of PI9 on tumor NK-cells seems to be a poor prognostic factor in NKTCL [81]. This paradoxical association was discussed in detail by the authors, which hypothesized that the loss of PI9 in NKTCL could reflect a dedifferentiation process associated with tumor progression involving the PI9 gene, with either gene deletion or inactivation due aberrant promoter hypermethylation as described for other genes such as P73 [81,82]. As also stated by the authors, other aspect to consider is the balance between pro-apoptotic (granzymes $\mathrm{B}$ and $\mathrm{M}$ ) and anti-apoptotic (PI9) proteins. Indeed, the granzyme B released from intracellular granules into the cytoplasm of NK cells is rapidly inactivated by forming complexes with PI9, thereby protecting the NK-cells from a premature cell death; in turns PI9 may become inactivated through its cleavage by granzyme $\mathrm{M}[83,84]$, which is also expressed in the NK tumor cells $[83,85]$.

\section{Mechanism Used by EBV to Induce Cell Transformation}

The HHVs, which include, among others, the EBV, also referred to as HHV-4, and the Kaposi's sarcoma associated herpes virus (KSHV), also known as HHV-8, are known by their ability to induce cell transformation and oncogenesis. They are large double-stranded DNA viruses and are able to establish a lifelong latency in lymphoid cells, during which only a few viral genes are expressed and the viral genome persists as circular episomes. Episomes contain repetitive sequences that serve as binding sites for the viral DNA binding proteins, such as the EBNA-1 of EBV and Latency-Associated Nuclear Antigen (LANA1) of KSHV which are expressed during latency, associate with the viral genome and tether it to host chromosomes, assuring persistence of the virus [86]. This is crucial for virus survival, but also induces cell transformation and promotes oncogenesis, as some of the latency proteins and viral noncoding RNAs and micro-RNAs have biological properties that lead to immortalization of the infected host cells [87-127].

\section{EBV Nuclear Antigens (EBNA)}

The EBNA proteins act mainly by maintaining the virus in an episomal form and regulating the transcription of viral and cellular genes (Table 2) [87-104]

EBNA-1: EBNA-1, which is typically expressed in most EBV-related malignancies, binds to target sites on the viral DNA and controls episomal maintenance and replication, in concert with replication of the host cells. In addition, it acts as a transcriptional regulator allowing viral gene expression in latency, being therefore necessary for cell transformation [87]. Among other effects, it confers resistance to apoptosis by up-regulating the apoptosis suppressor protein survivin [88]. It also induces the Recombination Activating Genes (RAG), whose products, RAG-1 and -2 , are essential for immunoglobulin and T-cell Receptor (TCR) gene recombination and increases in the levels of reactive oxygen species, resulting in genomic instability $[89,90]$. Furthermore, EBNA-1 interacts with regulatory proteins, including the HHV-associated ubiquitin-specific protease (HAUSP, USP7) and the karyopherins [91,92]. It also inhibits antigen processing and cell surface presentation by binding the TAP complex [93].

EBNA-2: The EBNA-2 is involved in transactivation of both viral and cellular gene promoters, such as LMP-1 and the EBNA Cp promoters, an effect that is at least partially mediated by the interaction with the cellular DNA binding proteins, J kappa and PU.1 [94,95]. The centromere binding factor $1 /$ recombining binding protein suppressor of hairless (CBF1/RBP-J kappa), a nuclear component of the Notch signaling pathway, is the most extensively studied partner $[96,97]$. The cleaved product of Notch is targeted to the nucleus where it binds to CBF1/RBP-Jkappa, and activates transcription. EBNA-2 induced upregulation of cellular anti-apoptotic genes, such as bfl-1, also requires CBF1/RBP-J kappa [97].

EBNA-3 family proteins: The EBNA-3 family proteins (3A, 3B and $3 \mathrm{C})$ are able to inhibit EBNA-2 induced transactivation by interacting with two isoforms of J kappa (J kappa-1 and RBP-2N), thus being able to down-regulate J kappa-mediated transcription [97-101].

EBNA-LP: EBNA-LP acts mainly by co-activating EBNA-2-dependent transcription and binds to heat shock proteins (HSP) and other cellular proteins, such as DNA-protein kinases catalytic subunit (DNA-PK) and HA95 [102-104].

\section{Latent Membrane Proteins (LMP)}

The EBV-infected cells express three LMP (LMP-1, LMP-2A, and LMP-2B) during latency programs II and III, which interact with several cellular signaling pathways, thereby promoting the proliferation and survival of the infected cells and inducing cell transformation (Table 3) [105-118]. 


\begin{tabular}{|c|c|c|c|c|}
\hline EBNA & Relevant functions & Examples of major interactions & $\begin{array}{l}\text { Evidence for role in } \\
\text { cell transformation }\end{array}$ & References \\
\hline EBNA-1 & $\begin{array}{l}\text { Important for the maintenance of viral episomes, viral DNA } \\
\text { replication, and transcriptional activation of latent EBV genomes; } \\
\text { implicated in cell immortalization and transformation; implicated } \\
\text { in immune evasion. }\end{array}$ & $\begin{array}{l}\text { HAUSP (USP7), Karyopherins } 2 \alpha \text { and } \\
\beta ; \text { TAP/p32 }\end{array}$ & Yes & [87-93] \\
\hline EBNA-2 & Activation of viral and cellular promoters & PU.1; CBF1/ RBP-J kappa & Yes & [94-97] \\
\hline EBNA-3A (EBNA-3) & Repression of the CBF1/RBP-J kappa dependent transcription & CBF1/RBP-J kappa; RBP-2N & Yes & {$[98,101]$} \\
\hline EBNA-3B (EBNA-4) & - & CBF1/RBP-J kappa; RBP-2N & No & [101]. \\
\hline EBNA-LP (EBNA-5) & Co-activation of EBNA-2-dependent transcription & $\begin{array}{l}\text { Hsp27; Hsp70 (Hsp72); Hsc70 (Hsp73); } \\
\text { HAX-1; HA95; alpha \& beta tubulins; } \\
\text { prolyl-4-hydroxylase alpha-1 subunit; } \\
\text { p14ARF; Fte-1/S3a }\end{array}$ & Yes & {$[102-104]$} \\
\hline EBNA-3C (EBNA-6) & Repression of the CBF1/RBP-J kappa dependent transcription & CBF1/RBP-J kappa; RBP-2N & Yes & [99-101] \\
\hline
\end{tabular}

CBF1: Centromere Binding Factor 1; HAUSP: Herpes Virus-Associated Ubiquitin-Specific Protease (USP7); HAX-1: HCLS1-Associated Protein X-1; HSP: Heath Shock Proteins; RBP: Recombining Binding Protein Suppressor of Hairless; RBP-2N: Recombination Signal Sequence-Binding protein 2N; TAP, Transporrter Associated with Antigen Processing

Table 2: Functions and interactions of the EBV nuclear antigens (EBNA)

LMP-1: LMP-1 acts as a constitutively activated receptor functionally homologous to the Tumour Necrosis Factor Receptor (TNFR) family members, such as CD40, thereby mimicking the CD40 signaling, activating the nuclear factor $\kappa \mathrm{B}(\mathrm{NF}-\kappa \mathrm{B})$ pathway and promoting cell survival [105-107]. Other signaling systems, such as the c-Jun N-terminal Kinase (JNK) and Janus kinase / Signal transducers and activators of transcription (JAK/STAT) -pathways, are also activated by LMP-1. In addition, LMP-1 up-regulates anti-apoptotic proteins, including $\mathrm{A} 20$ and $\mathrm{Bcl}-2[108,109]$. It may also alter the ratio of caspase-8, an initiator caspase, and its competitor FLIP (FLICE inhibitory protein) [110]. Moreover, LMP-1 induces the expression of the intercellular adhesion molecule -1 (ICAM-1) and the leukocyte function adhesion molecule (LFA) [109]. Finally, LMP-1 expressed in epithelial cells inhibits DNA repair and induces micronuclei formation, chromosomal aberrations, and genomic instability [111].

LMP-2A and LMP-2B: LMP-2A and LMP-2B, which are generated by alternative splicing, interact with $\mathrm{SH} 2$-domain-containing proteins, such as the immunoglobulin receptor-induced kinase Lyn. Together with LPM-1, LMP-2A promotes lymphoma cell survival via TNF Receptor Associated Factor (TRAF) 2 regulation of the NF- $\kappa B$ [112]. In addition, it possesses an Immunoreceptor Tyrosine-Based Activation Motif (ITAM) which binds the Syk kinase in its activated state and mimics the B-cell Receptor (BCR) signal [113]. Thus, LMP$2 \mathrm{~A}$ promotes $\mathrm{B}$ cell survival in the absence of normal BCR signalling, suggesting a role in helping EBV-infected cells to persist in vivo [114]. In addition, EBV mutants with a deleted LMP-2A gene fail to allow germinal centre $B$ cells to survive [115]. However, there is also evidence that LMP2A blocks the signalling function of the BCR, excludes the BCR from entering the lipids rafts and blocks antigen trafficking and processing functions [116]. LMP-2A has also been shown to activate phospho-inositide 3-kinase (PI3) and the downstream phosphorylation of PKB (protein kinase B, also known as Akt) inside epithelial cells and $\mathrm{B}$ cells, which may modulate cell growth and apoptosis, as well as to induce epithelial cell mobility and invasion $[117,118]$.

\section{EBV Non Coding RNAs}

Non-coding RNAs from viral origin (EBERs) play important immunoregulatory functions by interacting with cellular proteins, and EBV non-coding micro-RNAs act by suppressing the expression of viral and host cell genes (Table 4) [119-127].

EBV-encoded RNAs: The EBERs are expressed abundantly in latently EBV-infected cells and interact with various cellular proteins, playing a key role in modulating the anti-viral immunity, as well as in cell survival and cell growth [119]. They bind the protein kinase RNAdependent (PKR) and inhibit its activation, leading to resistance to PKR-mediated apoptosis. EBERs also bind retinoic-acid inducible gene I (RIG-I), a sensor of innate immunity, and activate its downstream signalling, which induces expression of type-I interferons (IFN). Furthermore, they induce IL-10 in Burkitt's lymphoma cells, an effect produced via RIG-I-mediated activation of IRF-3. It was reported that the EBERs secreted from EBV-infected cells are recognized by the tolllike receptor type 3 (TLR3), leading to induction of type-I IFNs and inflammatory cytokines. In addition, EBERs induce the expression Insulin-Like Growth Factor (IGF)-1 in carcinoma cells and IL-9 in T cells. Furthermore, EBER-2 plays a critical role in B cell growth transformation by inducing IL-6 production [120].

EBV micro-RNAs: Micro-RNAs (mi-RNAs) are small non-coding single stranded RNAs that down-regulate gene expression at the posttranscriptional level, by binding mRNAs bearing complementary sequences. EBV encodes dozens of mi-RNAs which can be divided into two groups: BHRF1 mi-RNAs and BART mi-RNAs [121-123]. Viral mi-RNAs interfere with the expression of viral and cellular genes and deregulate the mi-RNA profile of the host cells, in order to establish a latent infection, to inhibit the apoptosis and to promote the cell cycle progression [121-123]. They are expressed in all forms of latency, and they may play a central role in the EBV-induced tumorigenesis $[124,125]$. The mi-RNA profiling of diffuse large B-cell lymphoma and NKTCL showed that only $2 \%$ of the mi-RNAs are derived from the virus, while viral mi-RNAs comprise up to $20 \%$ of the total miRNA in nasopharyngeal carcinoma. Some of the targets identified so far are the mRNAs codifying for caspase 3, p53 up-regulated modulator of apoptosis (PUMA), interleukin 1 alpha (IL-1A), IFN-inducible T-cell attracting chemokine (ITAC, CXCL11) and BCL6 (B-cell CLL/ lymphoma type 6) protein [124-127].

\section{Chronic Active Ebv-Infection And Ebv-Related Lymphoproliferative Disorders}

Chronic active EBV (CAEBV) infection may develop in some individuals, as a result of an inappropriate control of viral replication, giving rise to EBV-associated lymphoproliferative disorders (EBVLPD), which include both pre-malignant and malignant conditions [128-150].

\section{Chronic active EBV infection}


Citation: Lima M (2013) Aggressive Mature Natural Killer Cell Neoplasms: From Ebv-Infection to Disease Etiopathogeny. J Blood Disorders Transf 5: 193. doi: 10.4172/2155-9864.1000193

Page 6 of 11

\begin{tabular}{|c|c|c|c|c|}
\hline LMP & Relevant functions & $\begin{array}{l}\text { Examples of major } \\
\text { interactions }\end{array}$ & $\begin{array}{l}\text { Evidence for role in } \\
\text { oncogenesis }\end{array}$ & References \\
\hline LMP-1 & $\begin{array}{l}\text { Constitutively activated receptor functionally homologous to CD40 / mimics CD40 signaling. } \\
\text { Activates the NFkB, JNK kinase, JAK/STAT, MAPK and PKC pathways. } \\
\text { Up-regulates anti-apoptotic proteins, including A20 and BCL2. } \\
\text { Induces cell adhesion and immune regulatory membrane proteins. } \\
\text { Inhibits DNA repair and induces micronuclei formation, chromosomal aberrations, and genomic } \\
\text { instability. }\end{array}$ & $\begin{array}{l}\text { RAF } 1,2,3 \\
\text { TRADD } \\
\text { BRAM } 1 \\
\text { LMP-2A }\end{array}$ & $\begin{array}{l}\text { Yes (anti-apoptotic } \\
\text { effect; survival of lym- } \\
\text { phoma cells; tumors in } \\
\text { transgenic animals) }\end{array}$ & {$[105-111]$} \\
\hline LMP-2A & $\begin{array}{l}\text { Interacts with Src- and Syk-families of tyrosine kinases. } \\
\text { Activates PI3 kinase and the downstream phosphorylation of PKB. } \\
\text { Mimics a BCR-like activation signal / provides B cells with survival signals in the absence of } \\
\text { normal BCR signaling. } \\
\text { Blocks lytic cycle / maintains viral latency. } \\
\text { Blocks BCR activation. } \\
\text { Induces epithelial cell mobility and invasion. } \\
\text { Promotes lymphoma cell survival via TRAF2 regulation of NF-kB. }\end{array}$ & $\begin{array}{l}\text { Src-family tyrosine } \\
\text { kinases (Src, Lyn, } \\
\text { Lck) } \\
\text { Syk-family tyrosine } \\
\text { kinases } \\
\text { (Syk, ZAP-70) } \\
\text { AlP4/Nedd4 }\end{array}$ & $\begin{array}{l}\text { Yes (survival of B-cells } \\
\text { and lymphoma cells; cell } \\
\text { migration and invasion) }\end{array}$ & {$[112-118]$} \\
\hline LMP-2B & Modulates LMP-2A function & LMP-2A & No & \\
\hline
\end{tabular}

AIP4: Atrophin-1-Interacting Protein 4 (Nedd4-Like E3 Ubiquitin Ligase); BCR: B-Cell Receptor; BRAM: BMP Receptor Associated Molecule; JAK: Janus Kinase; JNK: CJun N-Terminal Kinases; LMP: Epstein Barr Virus-Encoded Latent Membrane Protein; MAP: Mitogen-Activated Protein Kinase; NEDD4: Neural Precursor Cell Expressed Developmentally Down-Regulated Protein 4 (E3 Ubiquitin Ligase); Nfkb: Nuclear Factor KB; RAF: Rapidly Accelerated Fibrosarcoma Kinases; PKB: Protein Kinase B:Also Known As Akt; Tumor Necrosis Factor Receptor Type 1-Associated DEATH Domain Protein; Src: Short For "Sarcoma" (Tyrosine Kinase); Syk: Spleen Tyrosine Kinase (Member Of The Syk Family Tyrosine Kinase); TRAF: TNF Receptor Associated Factor; ZAP-70: Zeta-Chain-Associated Protein Kinase 70

Table 3: Functions and interactions of the EBV latent membrane proteins (LMP).

\begin{tabular}{|c|c|c|c|c|c|c|c|}
\hline $\begin{array}{l}\text { EBV non- } \\
\text { coding RNAs }\end{array}$ & $\begin{array}{l}\text { Main char- } \\
\text { acteristics }\end{array}$ & \multicolumn{2}{|l|}{ Types } & Relevant functions & Examples of major interactions & Major effects & References \\
\hline $\begin{array}{l}\text { EBV- RNAs } \\
\text { (EBERs) }\end{array}$ & $\begin{array}{l}\text { Non-coding, } \\
\text { non-poly }(A) \\
\text { RNAs }\end{array}$ & \multicolumn{2}{|c|}{$\begin{array}{l}\text { EBER-1 } \\
(166 \text { nts }) \\
\text { EBER-2 } \\
\text { (172 nts) }\end{array}$} & $\begin{array}{l}\text { Act as regulators of sig- } \\
\text { naling and transcription } \\
\text { factors. }\end{array}$ & $\begin{array}{l}\text { Resistance to PKR-mediated apoptosis due to PKR binding. } \\
\text { Production of type-I IFN through RIG-I binding. } \\
\text { Production of IL-10 via RIG-I-mediated activation of IRF-3 } \\
\text { (Burkitt's lymphoma). } \\
\text { Expression of IGF-1 (gastric and nasopharyngeal carcinoma). } \\
\text { Production of IL-9 (T-cells) and IL-6 (B-cells). }\end{array}$ & $\begin{array}{l}\text { Cell transfor- } \\
\text { mation }\end{array}$ & [119-120] \\
\hline $\begin{array}{l}\text { EBV micro- } \\
\text { RNAs } \\
\text { (mi-RNAs) }\end{array}$ & $\begin{array}{l}\text { Small } \\
\text { non-coding } \\
\text { RNAs }\end{array}$ & BHRF1 & $\begin{array}{l}\text { Dozens mi- } \\
\text { RNAs } \\
(19-95 \text { nts })\end{array}$ & $\begin{array}{l}\text { Down-regulate the } \\
\text { expression of mRNAs } \\
\text { bearing complementary } \\
\text { sequences. }\end{array}$ & $\begin{array}{l}\text { PUMA of the p53 pathway. } \\
\text { BCL6. } \\
\text { Caspase } 3 . \\
\text { ITAC / CXCL11. } \\
\text { IL-1. }\end{array}$ & $\begin{array}{l}\text { Resistance } \\
\text { to apoptosis / } \\
\text { cell survival }\end{array}$ & {$[121-127]$} \\
\hline
\end{tabular}

BCL6: B-Cell CLL/Lymphoma Protein Type 6; IFN: Interferon; IL-1: Interleukin 1; IGF-1: Insulin-Like Growth Factor; IRF-3: Interferon Regulatory Transcription Factor 3 ; ITAC: IFN-Inducible T-Cell Attracting Chemokine; ntd: Nucleotides; PKR: Protein Kinase RNA-Dependent Receptor; Poly(A): Polyadenylated; PUMA: P53 Up-Regulated Modulator Of Apoptosis; RIG-I: Retinoic-Acid Inducible Gene I

Table 4: Functions and interactions of the EBV non-coding RNAs.

Patients with congenital or acquired immunodeficiency are at increased risk for EBV-LPD, which are in nearly all instances of B-cell lineage, but the virus has been implicated in various kinds of epithelial tumors, as well as in the genesis of T- and NK-cell LPD. These are rare in western countries but relatively frequent in Asia, where they usually affect children without underlying immunodeficiencies and at times lead to the development of T- or NK-cell neoplasms. Differences in host immune responses and EBV strains may account for the development of different LPD and dominant T helper (Th) 2 and Th1 responses may exert in EBV associated B-LPD and T/NK-LPD, respectively [55].

\section{EBV-associated T/NK lymphoproliferative disorders}

EBV-associated T/NK-cell LPD comprise a large spectrum of polyclonal, oligoclonal and monoclonal proliferations of EBV-infected $\mathrm{T}$ - or NK-cells in which at least four entities have been distinguished from the clinical point of view, with overlapping features: Chronic Active EBV Infection (CAEBV), EBV-associated hemophagocytic lymphohistiocytosis (HLH), Severe Mosquito Bite Allergy (SMBA) and Hydroa Vacciniforme (HV) (Table 5) [128-150]. These latter three entities are part of the spectrum of CAEBV, with a broad range of clinical manifestations, which are closely linked with the immunophenotype of the EBV-infected cells, as SMBA usually associated with EBV+ NKcells whereas $\mathrm{HV}$ often associates with $\mathrm{EBV}+$ gamma delta T-cells
$[130,131]$. The WHO classification recognizes two neoplastic entities in the group of the EBV-positive T-cell LPD of childhood: systemic EBV+ T-cell LPD of childhood and HV-like lymphoma [132].

A prospective study of 108 non-immunocompromised patients with T-cell (64 cases) or NK-cell (44 cases) EBV-associated LPD, including 80 cases of CAEBV, 15 cases of EBV-associated HLH, 9 cases of HMB and 4 cases of $\mathrm{HV}$, showed that during a median follow-up period of 46 months, $44 \%$ of patients died of severe disease complications and $12 \%$ of patients developed NK-cell neoplasms, either extranodal T- or NKTCL or ANKCL [131]. While a number of therapies have been tried including antiviral agents, cytokines, such as IFN-gamma and IL-2, chemotherapy (etoposide), corticosteroids, cyclosporine, and EBVspecific CTL, the results are not satisfactory. More promising results have been obtained with related or unrelated BM transplantation using myeloablative or non-myeloablative regimens, a procedure that eliminates the EBV-infected cells, reconstitutes the EBV-specific cellular immunity, and induces a graft-versus-tumor effect, although it carries a high risk of transplantation-related complications [133-136].

Chronic active EBV disease: Chronic active EBV (CAEBV) disease is a prolonged ( $\geq 3$ months duration) infectious mononucleosislike illness caused by EBV $[137,138]$. This EBV-LPD is rare and predominantly occurs in East Asian countries, where it results from 


\begin{tabular}{|c|c|c|c|c|}
\hline Disease type & Criteria for diagnosis & Exclusion criteria & EBV+ cells & References \\
\hline $\begin{array}{l}\text { Chronic active EBV } \\
\text { disease (CAEBV) }\end{array}$ & $\begin{array}{l}\text { 1) EBV-related illness with } \geq 3 \text { months duration } \\
\text { 2) Disease manifestations may include fever, hepatitis, adenopa- } \\
\text { thies, hepatosplenomegaly, pancytopenia, uveitis, pneumonitis, } \\
\text { hydroa vacciniforme-like skin eruptions and hypersensitivity to } \\
\text { mosquito bites. } \\
\text { 3) EBV detected by Southern blot hybridization or EBER-positive } \\
\text { cells in affected tissues or peripheral blood; } \geq 10^{2.5} \text { copies } / \mu \text { go } \\
\text { EBV DNA in peripheral blood mononuclear cells; titers of anti- } \\
\text { EBV IgG antibodies: anti-VCA } \geq 5120 \text { or anti-EA }>640 \text {. }\end{array}$ & $\begin{array}{l}\text { 1) Other immunological abnormali- } \\
\text { ties or infections that might explain the } \\
\text { observed condition. } \\
\text { 2) Congenital immunodeficiency } \\
\text { including X-linked lymphoproliferative } \\
\text { disorders. }\end{array}$ & $\begin{array}{l}\text { T-cells } \\
\text { or } \\
\text { NK-cells }\end{array}$ & {$[129,137,138,141]$} \\
\hline $\begin{array}{l}\text { Hemophagocytic } \\
\text { lymphohistiocytosis } \\
(\mathrm{HLH})\end{array}$ & $\begin{array}{l}\text { 1) Fever and splenomegaly } \\
\text { 2) Cytopenias affecting two or three lineages, hypertriglyceride- } \\
\text { mia, and/or hypofibrinogenemia. } \\
\text { 3) Hemophagocytosis in the BM, spleen and/or LN. }\end{array}$ & $\begin{array}{l}\text { 1) Hemophagocytic syndrome in acceler- } \\
\text { ated phase of CAEBV. } \\
\text { 2) Congenital immunodeficiency includ- } \\
\text { ing familial HLH. }\end{array}$ & $\begin{array}{l}\text { T-cells } \\
\text { or } \\
\text { NK-cells }\end{array}$ & {$[129,142]$} \\
\hline $\begin{array}{l}\text { Severe mosquito } \\
\text { bite allergy (SMBA) }\end{array}$ & $\begin{array}{l}\text { Hypersensitivity to mosquito bites, characterized by high fever } \\
\text { after mosquito bites, ulcers, necrosis, and scarring. }\end{array}$ & \multirow{2}{*}{$\begin{array}{l}\text { Patients with systemic symptoms in } \\
\text { addition to the cutaneous lesions are } \\
\text { categorized as CAEBV. }\end{array}$} & NK-cells & {$[129,145,146]$} \\
\hline $\begin{array}{l}\text { Hydroa vaccin- } \\
\text { iforme }(\mathrm{HV})\end{array}$ & $\begin{array}{l}\text { Recurrent vesiculo-papules with central umbilication and crust } \\
\text { formation, usually occurring on the sun-exposed areas. }\end{array}$ & & $\begin{array}{l}\text { T-cells (usually } \\
\text { gamma / delta) }\end{array}$ & {$[129,149,150]$} \\
\hline
\end{tabular}

BM: Bone Marrow; CAEBV: Chronic Active EBV Disease; EA: Early Antigen; EBV: Epstein Barr Virus; HLH: EBV-Associated Hemophagocytic Lymphohistiocytosis; HV: Hydroa Vacciniforme; LN: Lymph Nodes; NK: Natural Killer; SMBA: Severe Mosquito Bite Allergy; VCA: Viral Capsid Antigen

'Severe mosquito bites allergy' and 'hydroa vacciniforme' are used as clinical categories, while the terms 'hypersensitivity to mosquito bites' and 'hydroa vacciniforme-like eruptions' were used to designate disease manifestations

Table 5: Epstein Barr virus related T/NK-cell lymphoproliferative disorders.

the expansion of EBV-infected T- or NK-cells, while in the western countries it is usually associated with EBV-infected B-cells [139]. It presents mainly in children, although adults can also be affected [140]. Clinical manifestations include fever, pancytopenia, adenopathies, hepatosplenomegaly, organ inflammatory diseases such as hepatitis, uveitis, interstitial pneumonitis, nephritis, as well as cutaneous manifestations, such as $\mathrm{HV}$ eruptions, and hypersensitivity to mosquito bites [141]. A Japanese survey of 82 patients with CAEBV showed that the disease has a high-morbidity and mortality and revealed that patients with late onset of disease, thrombocytopenia, and T/NK-cell infection have poorer outcomes [138].

EBV-associated hemophagocytic lymphohistiocytosis: EBVassociated Hemophagocytic Lymphohistiocytosis (HLH) manifests mainly as a Hemophagocytic Syndrome (HS) involving the BM or other organs and resulting in pancytopenia [142]. As CAEBV disease, the HLH is also more frequently seen in the East Asian countries, where it affects mostly children, although it may also present in adults [143]. It results from the expansion of EBV+ T-cells or NK- cells which produce inflammatory cytokines, thereby inducing macrophage activation and hemophagocytosis [144]. Patients usually have fever, splenomegaly and cytopenias, hypertriglyceridemia and hypofibrinogenemia, and hemophagocytosis in the BM, spleen, and/or LN [142].

Severe mosquito bites allergy: Severe Mosquito Bite Allergy (SMBA) is a syndrome characterized by fever and a skin reaction to mosquito bites consisting of ulcers, necrosis, and scarring, usually designated as Hypersensitivity to mosquito Bites (HSB) [145,146]. Although it was thought for a long time to represent a severe allergic reaction, it has become evident its relationship to EBV infection, as HMB may also occur as one of the manifestations of the CAEBV and has a great potential to develop into NK-cell malignancies, half of the patients with HMB / SMBA dying from HS or NK-cell neoplasms $[137,138]$. In fact, clinical and laboratory studies revealed that HMB / SMBA occur in association with EBV+ chronic NK-cell lymphocytosis (CNKCL) and the HMB skin lesions are infiltrated by EBV+ NKcells $[145,146]$. Some studies have demonstrated a close relationship between $\mathrm{HMB}$, mosquito antigen-specific CD4+ T-cells and EBV+ NK-cells: CD4+ T-cells, but not NK-cells, from the patients with HMB
/ SMBA proliferate in response to mosquito salivary gland extracts, and when co-cultured with NK-cells, enhance the expression of the viral oncogenes on NK-cells, such as LMP-1, suggesting that mosquito antigen-specific CD4+ T-cells may play a key role in the development of HMB / SMBA and NK-cell neoplasms via the induction of EBV reactivation and oncogene expression [147,148].

Hydroa vacciniforme: Hydroa Vacciniforme (HV) is an EBV-related disease that manifests in childhood as a photosensitivity disorder although HV lesions can also be observed in patients with CAEBV. The most frequent skin manifestations include redness, blisters and bumps, scars, itching, and burning, predominantly on sun-exposed areas; other common manifestations are oral ulcers, eye ulcers and abdominal pain $[149,150]$. The majority of the EBV-infected cells are gamma/delta T-cells [130].

\section{Conclusion}

The EBV is a ubiquitous HHV that leads to a lifelong infection which is continually checked by the immune system. The virus uses multiple mechanisms to evade the immune surveillance and its genome encodes for multiple products that interact with, or exhibit homology to, a wide variety of molecules with important biological effects, such as anti-apoptotic factors, growth factor receptors, cytokines and signal transducers, thereby promoting both EBV infection and cell immortalization and transformation.

EBV-related diseases occur when the immune system fails to control the virus, leading to a chronic active EBV infection and associated LPD and/or when EBV-related malignancies develop. In western countries, the EBV-related LPD and lymphoid neoplasms are in nearly all instances of B-cell lineage and usually occur in patients with congenital or acquired immunodeficiency. However, the virus has also been implicated in the genesis of the T- and NK-cell LPD, especially in Asia, where they affect children without known underlying immunodeficiencies and lead to the development of T- or NK-cell tumors.

\section{Acknowledgement}

The author thanks to the medical doctors (Catarina Lau, Maria dos Anjos Teixeira) and other professionals (Ana Helena Santos, Lurdes Oliveira, Maria 
Citation: Lima M (2013) Aggressive Mature Natural Killer Cell Neoplasms: From Ebv-Infection to Disease Etiopathogeny. J Blood Disorders Transf 5: 193. doi: 10.4172/2155-9864.1000193

Page 8 of 11

Luís Queirós, Marlene Santos, Marta Gonçalves and Sónia Fonseca) and collaborators (João Rodrigues, Magdalena Leander) of the Cytometry Laboratory for the support concerning NK-cell immunophenotyping and diagnosis of NK-cells lymphoproliferative disorders. She also thanks to the medical doctors who have referred patients with suspicion of NK-cell LPD for study.

\section{References}

1. Odumade OA, Hogquist KA, Balfour HH Jr (2011) Progress and problems in understanding and managing primary Epstein-Barr virus infections. Clin Microbiol Rev 24: 193-209.

2. Young LS, Rickinson AB (2004) Epstein-Barr virus: 40 years on. Nat Rev Cancer 4: 757-768.

3. Cheung MM, Chan JK, Wong KF (2003) Natural killer cell neoplasms: a distinctive group of highly aggressive lymphomas/leukemias. Semin Hematol 40: 221-232

4. Suzuki R, Suzumiya J, Nakamura S, Aoki S, Notoya A, et al. (2004) Aggressive natural killer-cell leukemia revisited: large granular lymphocyte leukemia of cytotoxic NK cells. Leukemia 18: 763-770.

5. Hasserjian RP, Harris NL (2007) NK-cell lymphomas and leukemias: a spectrum of tumors with variable manifestations and immunophenotype. Am J Clin Pathol 127: 860-868.

6. Oshimi K (2007) Progress in understanding and managing natural killer-cell malignancies. Br J Haematol 139: 532-544.

7. Aozasa K, Takakuwa T, Hongyo T, Yang WI (2008) Nasal NK/T-cell lymphoma: epidemiology and pathogenesis. Int J Hematol 87: 110-117.

8. Liang X, Graham DK (2008) Natural killer cell neoplasms. Cancer 112: 14251436.

9. Greer JP, Mosse CA (2009) Natural killer-cell neoplasms. Curr Hematol Malig Rep 4: 245-252.

10. Harabuchi Y, Takahara M, Kishibe K, Moriai S, Nagato T, et al. (2009) Nasa natural killer (NK)/T-cell lymphoma: clinical, histological, virological, and genetic features. Int J Clin Oncol 14: 181-190.

11. Kohrt H, Advani $\mathrm{R}$ (2009) Extranodal natural killer/T-cell lymphoma: current concepts in biology and treatment. Leuk Lymphoma 50: 1773-1784.

12. Gill H, Liang RH, Tse E (2010) Extranodal natural-killer/t-cell lymphoma, nasal type. Adv Hematol 2010: 627401.

13. Suzuki R (2010) Treatment of advanced extranodal NK/T cell lymphoma, nasaltype and aggressive NK-cell leukemia. Int J Hematol 92: 697-701.

14. Aozasa K, Zaki MA (2011) Epidemiology and pathogenesis of nasal NK/T-cell Iymphoma: a mini-review. ScientificWorldJournal 11: 422-428.

15. Kobayashi S (2011) Natural Killer Cell Leukemia: Diagnosis, Pathogenesis and Treatment. In: Faderl S (Edr.), Novel Aspects in Acute Lymphoblastic Leukemia. InTech.

16. Kwong YL (2011) The diagnosis and management of extranodal NK/T-cell lymphoma, nasal-type and aggressive NK-cell leukemia. J Clin Exp Hematop 51: 21-28.

17. Tse E, Kwong YL (2011) Treatment algorithms for mature T-cell and natural killer-cell neoplasms. Future Oncol 7: 1101-1112.

18. Semenzato G, Marino F, Zambello R (2012) State of the art in natural killer cell malignancies. Int J Lab Hematol 34: 117-128.

19. Lima M (2013) Aggressive mature natural killer cell neoplasms: from epidemiology to diagnosis. Orphanet J Rare Dis 8: 95.

20. Chisté M, Vrotsos E, Zamora C, Martinez A (2013) Chronic lymphocytic leukemia/small lymphocytic lymphoma involving the aortic valve. Ann Diagn Pathol 17: 295-297.

21. Chan JKC, Quintanilla-Martinez L, Ferry JA, Peh S-C (2008) Extranodal NK/Tcell lymphoma, nasal type. In: Swerdlow SH, Campo E, Harris NL, Jaffe ES, Pileri SA, Stein $\mathrm{H}$, et al., editors. World Health Organization Classification of Tumours of Haematopoietic and Lymphoid Tissues. (4th Edn,). International Agency for Research on Cancer (IARC), Lyon, France, PP: 285-258.

22. Chan JKC, Jane ES, Ralfkiaer E, Ko Y-H (2008) Aggressive NK-cell leukaemia In: Swerdlow SH, Campo E, Harris NL, Jaffe ES, Pileri SA, Stein H, et al. (Eds,) World Health Organization Classification of Tumours of Haematopoietic and
Lymphoid Tissues. (4th Edn,). International Agency for Research on Cancer (IARC), Lyon, France, pp: 276-277.

23. Villamor N, Morice WG, Chan WC, Foucar KK (2008) Chronic lymphoproliferative disorders of NK cells. In: Swerdlow SH, Campo EE, Harris NL, Jaffe ES, Pileri $\mathrm{SA}$, Stein $\mathrm{H}$, et al., (Eds,). World Health Organization Classification of Tumours of Haematopoietic and Lymphoid Tissues. (4th Edn,). International Agency for Research on Cancer (IARC), Lyon, France, pp: 274-275.

24. Kwong YL, Chan AC, Liang R, Chiang AK, Chim CS, et al. (1997) CD56+ NK lymphomas: clinicopathological features and prognosis. Br J Haematol 97: 821-829.

25. Au W-Y, Ma S-Y, Chim C-S, Choy C, Loong F, et al. (2005) Clinicopathologic features and treatment outcome of mature T-cell and natural killer-cel lymphomas diagnosed according to the World Health Organization classification scheme: a single center experience of 10 years. Ann Oncol 16: 206-214.

26. Liu J, Song B, Fan T, Huang C, Xie C, et al. (2011) Pathological and clinical characteristics of 1,248 non-Hodgkin's lymphomas from a regional cancer hospital in Shandong, China. Asian Pac J Cancer Prev 12: 3055-3061.

27. Gaal K, Sun NC, Hernandez AM, Arber DA (2000) Sinonasal NK/T-cell lymphomas in the United States. Am J Surg Pathol 24: 1511-1517.

28. Suzuki R, Suzumiya J, Oshimi K (2009) Differences between nasal and extranasal NK/T-cell lymphoma. Blood 113: 6260-6261.

29. Wong KF, Chan JK, Cheung MM, So JC (2001) Bone marrow involvement by nasa NK cell lymphoma at diagnosis is uncommon. Am J Clin Pathol 115: 266-270.

30. Takahashi N, Miura I, Chubachi A, Miura AB, Nakamura S (2001) A clinicopathological study of 20 patients with T/natural killer (NK)-cell lymphomaassociated hemophagocytic syndrome with special reference to nasal and nasal-type NK/T-cell lymphoma. Int J Hematol 74: 303-308.

31. Chan JK, Sin VC, Wong KF, Ng CS, Tsang WY, et al. (1997) Nonnasal lymphoma expressing the natural killer cell marker CD56: a clinicopathologic study of 49 cases of an uncommon aggressive neoplasm. Blood 89: 4501-4513.

32. Gualco G, Domeny-Duarte P, Chioato L, Barber G, Natkunam Y, et al. (2011) Clinicopathologic and molecular features of 122 Brazilian cases of nodal and extranodal NK/T-cell lymphoma, nasal type, with EBV subtyping analysis. Am J Surg Pathol 35: 1195-1203.

33. Chim CS, Ma ES, Loong F, Kwong YL (2005) Diagnostic cues for natural kille cell lymphoma: primary nodal presentation and the role of in situ hybridisation for Epstein-Barr virus encoded early small RNA in detecting occult bone marrow involvement. J Clin Pathol 58: 443-445.

34. Takahashi E, Asano N, Li C, Tanaka T, Shimada K, et al. (2008) Nodal T/ NK-cell lymphoma of nasal type: a clinicopathological study of six cases. Histopathology 52: 585-596.

35. Chang ST, Liao YL, Lin SH, Chuang SS (2010) NK-cell lymphoma with noda presentation and expression of cutaneous lymphocyte-associated antigen. Pathol Res Pract 206: 463-466.

36. Kagami Y, Suzuki R, Taji H, Yatabe Y, Takeuchi T, et al. (1999) Nodal cytotoxic lymphoma spectrum: a clinicopathologic study of 66 patients. Am J Surg Pathol 23: $1184-1200$

37. Ruskova A, Thula R, Chan G (2004) Aggressive Natural Killer-Cell Leukemia: report of five cases and review of the literature. Leuk Lymphoma 45: 2427 2438.

38. Oshimi K, Kawa K, Nakamura S, Suzuki R, Suzumiya J, et al. (2005) NK-cell neoplasms in Japan. Hematology 10: 237-245

39. Sino-US Shanghai Leukemia Cooperative Group (2006) [Aggressive NK-cell leukemia: report of nine cases and review of literature]. Zhonghua Xue Ye Xue Za Zhi 27: 116-119.

40. Ryder J, Wang X, Bao L, Gross SA, Hua F, et al. (2007) Aggressive natura killer cell leukemia: report of a Chinese series and review of the literature. Int J Hematol 85: 18-25.

41. Au WY, Weisenburger DD, Intragumtornchai T, Nakamura S, Kim WS, et al. (2009) Clinical differences between nasal and extranasal natural killer/Tcell lymphoma: a study of 136 cases from the International Peripheral T-Cel Lymphoma Project. Blood 113: 3931-3937.

42. Okuda T, Sakamoto S, Deguchi T, Misawa S, Kashima K, et al. (1991) Hemophagocytic syndrome associated with aggressive natural killer cell leukemia. Am J Hematol 38: 321-323. 
Citation: Lima M (2013) Aggressive Mature Natural Killer Cell Neoplasms: From Ebv-Infection to Disease Etiopathogeny. J Blood Disorders Transf 5: 193. doi: 10.4172/2155-9864.1000193

43. Akashi K, Mizuno S (2000) Epstein-Barr virus-infected natural killer cell leukemia. Leuk Lymphoma 40: 57-66.

44. Kaizu K, Maeda M, Ohkawa T, Hayashida M, Nakajima S, et al. (2004) Marked elevation of soluble fas ligand and cytokine secretion after splenectomy in aggressive natural killer cell leukemia/lymphoma. Leuk Lymphoma 45: 2291-2294.

45. Choi YL, Park JH, Kim WS, Lee DY, Lee JH, et al. (2006) Aggressive NKcell leukaemia associated with reactive haemophagocytic syndrome. Clin Exp Dermatol 31: 83-85.

46. Petterson TE, Bosco AA, Cohn RJ (2008) Aggressive natural killer cell leukemia presenting with hemophagocytic lymphohistiocytosis. Pediatr Blood Cancer 50: 654-657.

47. Suzuki S, Uozumi K, Utsunomiya A, Ishitsuka K, Masamoto I, et al. (2008) Aggressive NK cell leukaemia after splenectomy: association with CD95resistant memory T-cell proliferation and recalcitrant clinical course of haemophagocytic syndrome. Eur J Haematol 81: 236-241.

48. Han AR, Lee HR, Park BB, Hwang IG, Park S, et al. (2007) Lymphomaassociated hemophagocytic syndrome: clinical features and treatment outcome. Ann Hematol 86: 493-498.

49. Kanavaros P, Lescs MC, Brière J, Divine M, Galateau F, et al. (1993) Nasa T-cell lymphoma: a clinicopathologic entity associated with peculiar phenotype and with Epstein-Barr virus. Blood 81: 2688-2695.

50. Minarovits J, Hu LF, Imai S, Harabuchi Y, Kataura A, et al. (1994) Clonality expression and methylation patterns of the Epstein-Barr virus genomes in lethal midline granulomas classified as peripheral angiocentric $T$ cell lymphomas. J Gen Virol $75: 77-84$

51. Dambaugh T, Hennessy K, Chamnankit L, Kieff E (1984) U2 region of EpsteinBarr virus DNA may encode Epstein-Barr nuclear antigen 2. Proc Natl Acad Sci U S A 81: 7632-7636.

52. Tomita Y, Ohsawa M, Mishiro Y, Kubo T, Maeshiro N, et al. (1995) The presence and subtype of Epstein-Barr virus in B and T cell lymphomas of the sino-nasal region from the Osaka and Okinawa districts of Japan. Lab Investig 73: 190-196.

53. Boyle MJ, Vasak E, Tschuchnigg M, Turner JJ, Sculley T, et al. (1993) Subtypes of Epstein-Barr virus (EBV) in Hodgkin's disease: association between B-type EBV and immunocompromise. Blood 81: 468-474.

54. Zimber U, Adldinger HK, Lenoir GM, Vuillaume M, Knebel-Doeberitz MV, et al. (1986) Geographical prevalence of two types of Epstein-Barr virus. Virology 154: 56-66.

55. Ohga S, Nomura A, Takada H, Hara T (2002) Immunological aspects of Epstein-Barr virus infection. Crit Rev Oncol Hematol 44: 203-215.

56. Tabiasco J, Vercellone A, Meggetto F, Hudrisier D, Brousset P, et al. (2003) Acquisition of viral receptor by NK cells through immunological synapse. J Immunol 170: 5993-5998.

57. Tsurumi T, Fujita M, Kudoh A (2005) Latent and lytic Epstein-Barr virus replication strategies. Rev Med Virol 15: 3-15.

58. Chiang AK, Tao Q, Srivastava G, Ho FC (1996) Nasal NK- and T-cell lymphomas share the same type of Epstein-Barr virus latency as nasopharyngeal carcinoma and Hodgkin's disease. Int J Cancer 68: 285-290.

59. Hislop AD, Taylor GS, Sauce D, Rickinson AB (2007) Cellular responses to viral infection in humans: lessons from Epstein-Barr virus. Annu Rev Immunol 25: 587-617.

60. Klutts JS, Ford BA, Perez NR, Gronowski AM (2009) Evidence-based approach for interpretation of Epstein-Barr virus serological patterns. J Clin Microbiol 47 3204-3210.

61. Gulley ML (2001) Molecular diagnosis of Epstein-Barr virus-related diseases. J Mol Diagn 3: 1-10.

62. Gulley ML, Tang W (2010) Using Epstein-Barr viral load assays to diagnose, monitor, and prevent posttransplant lymphoproliferative disorder. Clin Microbio Rev 23: 350-366.

63. Wagner HJ, Wessel M, Jabs W, Smets F, Fischer L, et al. (2001) Patients at risk for development of posttransplant lymphoproliferative disorder: plasma versus peripheral blood mononuclear cells as material for quantification of EpsteinBarr viral load by using real-time quantitative polymerase chain reaction. Transplantation 72: 1012-1019.
64. Baldanti F, Grossi P, Furione M, Simoncini L, Sarasini A, et al. (2000) High levels of Epstein-Barr virus DNA in blood of solid-organ transplant recipients and their value in predicting post transplant lymphoproliferative disorders. J Clin Microbiol 38: 613-619.

65. Balfour HH Jr, Hokanson KM, Schacherer RM, Fietzer CM, Schmeling DO, et al. (2007) A virologic pilot study of valacyclovir in infectious mononucleosis. J Clin Virol 39: 16-21.

66. Wadowsky RM, Laus S, Green M, Webber SA, Rowe D (2003) Measurement of Epstein-Barr virus DNA loads in whole blood and plasma by TaqMan PCR and in peripheral blood lymphocytes by competitive PCR. J Clin Microbiol 41 5245-5249.

67. Griffin BD, Gram AM, Mulder A, Van Leeuwen D, Claas FH, et al. (2013) EBV BILF1 evolved to downregulate cell surface display of a wide range of HLA class I molecules through their cytoplasmic tail. J Immunol 190: 1672-1684.

68. Jochum S, Moosmann A, Lang S, Hammerschmidt W, Zeidler R (2012) The EBV immunoevasins vIL-10 and BNLF2a protect newly infected B cells from immune recognition and elimination. PLoS Pathog 8: e1002704.

69. Levitskaya J, Coram M, Levitsky V, Imreh S, Steigerwald-Mullen PM, et al. (1995) Inhibition of antigen processing by the internal repeat region of the Epstein-Barr virus nuclear antigen-1. Nature 375: 685-688.

70. Rickinson AB, Murray RJ, Brooks J, Griffin H, Moss DJ, et al. (1992) T cell recognition of Epstein-Barr virus associated lymphomas. Cancer Surv 13: 53-80.

71. Sin SH, Dittmer DP (2012) Cytokine homologs of human gammaherpesviruses. $\mathrm{J}$ Interferon Cytokine Res 32: 53-59.

72. Kato K, Ohshima K, Ishihara S, Anzai K, Suzumiya J, et al. (1998) Elevated serum soluble Fas ligand in natural killer cell proliferative disorders. $\mathrm{Br} J$ Haematol 103: 1164-1166.

73. Murayama T, Koizumi T, Das H, Kobayashi Y, Kajimoto K, et al. (1999) Soluble fas ligand in natural killer cell lymphoma. Am J Hematol 62: 253-255.

74. Makishima H, Ito T, Momose K, Nakazawa H, Shimodaira S, et al. (2007) Chemokine system and tissue infiltration in aggressive NK-cell leukemia. Leuk Res 31: 1237-1245.

75. Ohshima K, Haraoka S, Sugihara M, Suzumiya J, Kawasaki C, et al. (2000) Amplification and expression of a decoy receptor for fas ligand (DcR3) in virus (EBV or HTLV-I) associated lymphomas. Cancer Lett 160: 89-97.

76. Huang Y, de Reyniès A, de Leval L, Ghazi B, Martin-Garcia N, et al. (2010) Gene expression profiling identifies emerging oncogenic pathways operating in extranodal NK/T-cell lymphoma, nasal type. Blood 115: 1226-1237.

77. Rouget-Quermalet V, Giustiniani J, Marie-Cardine A, Beaud G, Besnard F, et al. (2006) Protocadherin 15 (PCDH15): a new secreted isoform and a potential marker for NK/T cell lymphomas. Oncogene 25: 2807-2811.

78. Ito M, Maruyama T, Saito N, Koganei S, Yamamoto K, et al. (2006) Killer cell lectin-like receptor $\mathrm{G} 1$ binds three members of the classical cadherin family to inhibit NK cell cytotoxicity. J Exp Med 203: 289-295.

79. Froelich CJ, Dixit VM, Yang X (1998) Lymphocyte granule-mediated apoptosis: matters of viral mimicry and deadly proteases. Immunol Today 19: 30-36.

80. Bladergroen B, Meijer CJLM, Ten Berge R, Hack CE, Muris JJF, et al. (2002 Expression of the granzyme $B$ inhibitor, protease inhibitor 9 , by tumor cells in patients with non-Hodgkin and Hodgkin lymphoma: a novel protective mechanism for tumor cells to circumvent the immune system? Blood 99: 232-237.

81. Bossard C, Belhadj K, Reyes F, Martin-Garcia N, Berger F, et al. (2007) Expression of the granzyme B inhibitor PI9 predicts outcome in nasal NK/Tcell lymphoma: results of a Western series of 48 patients treated with firstline polychemotherapy within the Groupe d'Etude des Lymphomes de l'Adulte (GELA) trials. Blood 109: 2183-2189.

82. Kawamata N, Inagaki N, Mizumura S, Sugimoto KJ, Sakajiri S, et al. (2005) Methylation status analysis of cell cycle regulatory genes (p16INK4A p15INK4B, p21Waf1/Cip1, p27Kip1 and p73) in natural killer cell disorders. Eur $\mathrm{J}$ Haematol 74: 424-429.

83. Hirst CE, Buzza MS, Bird CH, Warren HS, Cameron PU, et al. (2003) The intracellular granzyme B inhibitor, proteinase inhibitor 9 , is up-regulated during accessory cell maturation and effector cell degranulation, and its overexpression enhances CTL potency. J Immunol 170: 805-815.

84. Mahrus S, Kisiel W, Craik CS (2004) Granzyme M is a regulatory protease that inactivates proteinase inhibitor 9 , an endogenous inhibitor of granzyme $B$. Biol Chem 279: 54275-54282. 
Citation: Lima M (2013) Aggressive Mature Natural Killer Cell Neoplasms: From Ebv-Infection to Disease Etiopathogeny. J Blood Disorders Transf 5: 193. doi: 10.4172/2155-9864.1000193

Page 10 of 11

85. Krenacs L, Smyth MJ, Bagdi E, Krenacs T, Kopper L, et al (2003). The serine protease granzyme $M$ is preferentially expressed in NK-cell, gamma delta T-cell, and intestinal T-cell lymphomas: evidence of origin from lymphocytes involved in innate immunity. Blood 101: 3590-3593.

86. Collins CM, Medveczky PG (2002) Genetic requirements for the episoma maintenance of oncogenic herpesvirus genomes. Adv Cancer Res 84: 155-174.

87. Frappier $L$ (2012) Contributions of Epstein-Barr nuclear antigen 1 (EBNA1) to cell immortalization and survival. Viruses 4: 1537-1547.

88. Lu J, Murakami M, Verma SC, Cai Q, Haldar S, et al. (2011) Epstein-Barr Virus nuclear antigen 1 (EBNA1) confers resistance to apoptosis in EBV-positive B-lymphoma cells through up-regulation of survivin. Virology 410: 64-75.

89. Tsimbouri P, Drotar ME, Coy JL, Wilson JB (2002) bcl-xL and RAG genes are induced and the response to IL-2 enhanced in EmuEBNA-1 transgenic mouse lymphocytes. Oncogene 21: 5182-5187.

90. Gruhne B, Sompallae R, Marescotti D, Kamranvar SA, Gastaldello S, et al (2009) The Epstein-Barr virus nuclear antigen-1 promotes genomic instability via induction of reactive oxygen species. Proc Natl Acad Sci U S A 106: 23132318

91. Holowaty MN, Zeghouf M, Wu H, Tellam J, Athanasopoulos V, et al. (2003) Protein profiling with Epstein-Barr nuclear antigen-1 reveals an interaction with the herpesvirus-associated ubiquitin-specific protease HAUSP/USP7. J Biol Chem 278: 29987-29994.

92. Ito S, Ikeda M, Kato N, Matsumoto A, Ishikawa Y, et al. (2000) Epstein-bar virus nuclear antigen-1 binds to nuclear transporter karyopherin alpha1/NPI-1 in addition to karyopherin alpha2/Rch1. Virology 266: 110-119.

93. Wang Y, Finan JE, Middeldorp JM, Hayward SD (1997) P32/TAP, a cellular protein that interacts with EBNA-1 of Epstein-Barr virus. Virology 236: 18-29.

94. Sjöblom A, Nerstedt A, Jansson A, Rymo L (1995) Domains of the Epstein-Barr virus nuclear antigen 2 (EBNA2) involved in the transactivation of the laten membrane protein 1 and the EBNA Cp promoters. J Gen Virol $76: 2669-2678$.

95. Johannsen E, Koh E, Mosialos G, Tong X, Kieff E, et al. (1995) EpsteinBarr virus nuclear protein 2 transactivation of the latent membrane protein 1 promoter is mediated by J kappa and PU.1. J Virol 69: 253-262.

96. Chau CM, Deng Z, Kang H, Lieberman PM (2008) Cell cycle association of the retinoblastoma protein $\mathrm{Rb}$ and the histone demethylase LSD1 with the EpsteinBarr virus latency promoter Cp. J Virol 82: 3428-3437.

97. Pegman PM, Smith SM, D'Souza BN, Loughran ST, Maier S, et al. (2006) Epstein-Barr virus nuclear antigen 2 trans-activates the cellular antiapoptotic bfl-1 gene by a CBF1/RBPJ kappa-dependent pathway. J Virol 80: 8133-8144.

98. Maruo S, Johannsen E, Illanes D, Cooper A, Zhao B, et al. (2005) EpsteinBarr virus nuclear protein $3 A$ domains essential for growth of lymphoblasts: transcriptional regulation through RBP-Jkappa/CBF1 is critical. J Virol 79: 10171-10179.

99. West MJ (2006) Structure and function of the Epstein-Barr virus transcription factor, EBNA 3C. Curr Protein Pept Sci 7: 123-136.

100. Marshall D, Sample C (1995) Epstein-Barr virus nuclear antigen 3C is a transcriptional regulator. J Virol 69: 3624-3630.

101.Zhao B, Marshall DR, Sample CE (1996) A conserved domain of the EpsteinBarr virus nuclear antigens $3 \mathrm{~A}$ and $3 \mathrm{C}$ binds to a discrete domain of Jkappa. J Virol 70: 4228-4236.

102. Harada S, Kieff E (1997) Epstein-Barr virus nuclear protein LP stimulates EBNA-2 acidic domain-mediated transcriptional activation. J Virol 71: 66116618.

103. Kitay MK, Rowe DT (1996) Protein-protein interactions between Epstein-Barr virus nuclear antigen-LP and cellular gene products: binding of 70 -kilodalton heat shock proteins. Virology 220: 91-99.

104. Han I, Harada S, Weaver D, Xue Y, Lane W, et al. (2001) EBNA-LP associates with cellular proteins including DNA-PK and HA95. J Virol 75: 2475-2481.

105. Klein E, Teramoto N, Gogolák P, Nagy N, Björkholm M (1999) LMP-1, the Epstein-Barr virus-encoded oncogene with a B cell activating mechanism similar to CD40. Immunol Lett 68: 147-154.

106. Lam N, Sugden B (2003) CD40 and its viral mimic, LMP1: similar means to different ends. Cell Signal 15: 9-16.

107. Lam N, Sugden B (2003) LMP1, a viral relative of the TNF receptor family, signals principally from intracellular compartments. EMBO J 22: 3027-3038.

108. Henderson S, Rowe M, Gregory C, Croom-Carter D, Wang F, et al. (1991) Induction of bcl-2 expression by Epstein-Barr virus latent membrane protein 1 protects infected B cells from programmed cell death. Cell 65: 1107-1115.

109. Hatzivassiliou E, Mosialos G (2002) Cellular signaling pathways engaged by the Epstein-Barr virus transforming protein LMP1. Front Biosci 7: d319-329.

110. Tepper CG, Seldin MF (1999) Modulation of caspase-8 and FLICEinhibitory protein expression as a potential mechanism of Epstein-Barr virus tumorigenesis in Burkitt's lymphoma. Blood 94: 1727-1737.

111. Liu M-T, Chen Y-R, Chen S-C, Hu C-Y, Lin C-S, et al. (2004) Epstein-Barr virus latent membrane protein 1 induces micronucleus formation, represses DNA repair and enhances sensitivity to DNA-damaging agents in human epithelial cells. Oncogene 23: 2531-2539.

112. Guasparri I, Bubman D, Cesarman E (2008) EBV LMP2A affects LMP1 mediated NF-kappaB signaling and survival of lymphoma cells by regulating TRAF2 expression. Blood 111: 3813-3820.

113. Engels N, Yigit G, Emmerich CH, Czesnik D, Schild D, et al. (2012) EpsteinBarr virus LMP2A signaling in statu nascendi mimics a B cell antigen receptorlike activation signal. Cell Commun Signal 10: 9

114. Merchant M, Swart R, Katzman RB, Ikeda M, Ikeda A, et al. (2001) The effects of the Epstein-Barr virus latent membrane protein $2 A$ on $B$ cell function. Int $R e$ Immunol 20: 805-835.

115. Mancao C, Hammerschmidt W (2007) Epstein-Barr virus latent membrane protein $2 \mathrm{~A}$ is a B-cell receptor mimic and essential for B-cell survival. Blood 110: $3715-3721$

116. Dykstra ML, Longnecker R, Pierce SK (2001) Epstein-Barr virus coopts lipid rafts to block the signaling and antigen transport functions of the BCR Immunity 14: 57-67.

117. Swart R, Ruf IK, Sample J, Longnecker R (2000) Latent membrane protein 2A-mediated effects on the phosphatidylinositol 3-Kinase/Akt pathway. J Viro 74: $10838-10845$

118. Pegtel DM, Subramanian A, Sheen TS, Tsai CH, Golub TR, et al. (2005) Epstein-Barr-virus-encoded LMP2A induces primary epithelial cell migration and invasion: possible role in nasopharyngeal carcinoma metastasis. J Viro 79: $15430-15442$

119. Iwakiri D, Takada K (2010) Role of EBERs in the pathogenesis of EBV infection. Adv Cancer Res 107: 119-136.

120. Wu Y, Maruo S, Yajima M, Kanda T, Takada K (2007) Epstein-Barr virus (EBV)encoded RNA 2 (EBER2) but not EBER1 plays a critical role in EBV-induced B-cell growth transformation. J Virol 81: 11236-11245.

121.Barth S, Meister G, Grässer FA (2011) EBV-encoded miRNAs. Biochim Biophys Acta 1809: 631-640.

122. Cai X, Schäfer A, Lu S, Bilello JP, Desrosiers RC, et al. (2006) Epstein-Bar virus microRNAs are evolutionarily conserved and differentially expressed. PLoS Pathog 2: e23.

123. Seto E, Moosmann A, Grömminger S, Walz N, Grundhoff A, et al. (2010) Micro RNAs of Epstein-Barr virus promote cell cycle progression and prevent apoptosis of primary human B cells. PLoS Pathog 6: e1001063.

124. Vereide DT, Seto E, Chiu YF, Hayes M, Tagawa T, et al. (2013) Epstein-Barr virus maintains lymphomas via its miRNAs. Oncogene.

125. Motsch N, Alles J, Imig J, Zhu J, Barth S, et al. (2012) MicroRNA profiling of Epstein-Barr virus-associated NK/T-cell lymphomas by deep sequencing. PLoS One 7: e42193.

126. Choy EY, Siu KL, Kok KH, Lung RW, Tsang CM, et al. (2008) An Epstein-Barr virus-encoded microRNA targets PUMA to promote host cell survival. J Exp Med 205: 2551-2560.

127. Xia T, O'Hara A, Araujo I, Barreto J, Carvalho E, et al. (2008) EBV microRNAs in primary lymphomas and targeting of CXCL-11 by ebv-mir-BHRF1-3. Cancer Res 68: 1436-1442.

128. Yachie A, Kanegane $H$, Kasahara $Y$ (2003) Epstein-Barr virus-associated T-/ natural killer cell lymphoproliferative diseases. Semin Hematol 40: 124-132.

129. Cohen JI, Kimura H, Nakamura S, Ko Y-H, Jaffe ES (2009) Epstein-Barr virusassociated lymphoproliferative disease in non-immunocompromised hosts: a 
Citation: Lima M (2013) Aggressive Mature Natural Killer Cell Neoplasms: From Ebv-Infection to Disease Etiopathogeny. J Blood Disorders Transf 5: 193. doi: 10.4172/2155-9864.1000193

Page 11 of 11

status report and summary of an international meeting, 8-9 September 2008 Ann Oncol 20: 1472-1482.

130. Hirai Y, Yamamoto T, Kimura H, Ito Y, Tsuji K, et al. (2012) Hydroa vacciniforme is associated with increased numbers of Epstein-Barr virus-infected $\hat{I}^{3} \hat{\imath} ' T$ cells. J Invest Dermatol 132: 1401-1408.

131. Kimura H, Ito Y, Kawabe S, Gotoh K, Takahashi Y, et al. (2012) EBV-associated T/NK-cell lymphoproliferative diseases in nonimmunocompromised hosts: prospective analysis of 108 cases. Blood 119: 673-686.

132. Quintanilla-Martinez L, Kimura $H$, Jaffe ES (2008) EBV-positive T-cell lymphoproliferative disorders of childhood. In: Swerdlow SH, Campo E, Harris NL, Jaffe ES, Pileri SA, Stein H, et al., (Eds,). World Health Organisation Classification Tumours Haematopoietic and Lymphoid Tissues (4th Edn,) International Agency for Research on Cancer (IARC) Press, France, PP: 278280.

133. Okamura T, Hatsukawa Y, Arai H, Inoue M, Kawa K (2000) Blood stem-cel transplantation for chronic active Epstein-Barr virus with lymphoproliferation. Lancet 356: 223-224.

134. Kawa K, Okamura T, Yasui M, Sato E, Inoue M (2002) Allogeneic hematopoietic stem cell transplantation for Epstein-Barr virus-associated T/ NK-cell lymphoproliferative disease. Crit Rev Oncol Hematol 44: 251-257.

135. Okamura T, Kishimoto T, Inoue M, Honda M, Yamashita N, et al. (2003) Unrelated bone marrow transplantation for Epstein-Barr virus-associated T/ NK-cell lymphoproliferative disease. Bone Marrow Transplant 31: 105-111.

136. Sato E, Ohga S, Kuroda H, Yoshiba F, Nishimura M, et al. (2008) Allogeneic hematopoietic stem cell transplantation for Epstein-Barr virus-associated T/ natural killer-cell lymphoproliferative disease in Japan. Am J Hematol 83: 721 727.

137. Kimura H, Hoshino $Y$, Kanegane $H$, Tsuge I, Okamura T, et al. (2001) Clinical and virologic characteristics of chronic active Epstein-Barr virus infection. Blood 98: 280-286.

138. Kimura H, Morishima T, Kanegane H, Ohga S, Hoshino $Y$, et al. (2003) Prognostic factors for chronic active Epstein-Barr virus infection. J Infect Dis 187: $527-533$

139. Cohen JI, Jaffe ES, Dale JK, Pittaluga S, Heslop HE, et al. (2011) Characterization and treatment of chronic active Epstein-Barr virus disease: a 28-year experience in the United States. Blood 117: 5835-5849.
140. Isobe $Y$, Aritaka N, Setoguchi $Y$, Ito $Y$, Kimura H, et al. (2012) T/NK cell type chronic active Epstein-Barr virus disease in adults: an underlying condition fo Epstein-Barr virus-associated T/NK-cell lymphoma. J Clin Pathol 65: 278-282.

141. Okano M, Kawa K, Kimura H, Yachie A, Wakiguchi H, et al. (2005) Proposed guidelines for diagnosing chronic active Epstein-Barr virus infection. Am J Hematol 80: 64-69.

142. Henter JI, Horne A, Aricó M, Egeler RM, Filipovich AH, et al. (2007) HLH-2004: Diagnostic and therapeutic guidelines for hemophagocytic lymphohistiocytosis. Pediatr Blood Cancer 48: 124-131.

143. Fox CP, Shannon-Lowe C, Gothard P, Kishore B, Neilson J, et al. (2010) Epstein-Barr virus-associated hemophagocytic lymphohistiocytosis in adults characterized by high viral genome load within circulating natural killer cells. Clin Infect Dis 51: 66-69

144. Lay JD, Tsao CJ, Chen JY, Kadin ME, Su IJ (1997) Upregulation of tumor necrosis factor-alpha gene by Epstein-Barr virus and activation of macrophages in Epstein-Barr virus-infected T cells in the pathogenesis of hemophagocytic syndrome. J Clin Invest 100: 1969-1979.

145. Ishihara S, Okada S, Wakiguchi H, Kurashige T, Hirai K, et al. (1997) Clonal lymphoproliferation following chronic active Epstein-Barr virus infection and hypersensitivity to mosquito bites. Am J Hematol 54: 276-281.

146. Ishihara S, Yabuta R, Tokura Y, Ohshima K, Tagawa S (2000) Hypersensitivity to mosquito bites is not an allergic disease, but an Epstein-Barr virusassociated lymphoproliferative disease. Int J Hematol 72: 223-228.

147. Asada H, Saito-Katsuragi M, Niizeki H, Yoshioka A, Suguri S, et al. (2005) Mosquito salivary gland extracts induce EBV-infected NK cell oncogenesis via CD4 T cells in patients with hypersensitivity to mosquito bites. J Invest Dermatol 125: 956-961.

148. Asada H (2007) Hypersensitivity to mosquito bites: a unique pathogenic mechanism linking Epstein-Barr virus infection, allergy and oncogenesis. J Dermatol Sci 45: 153-160.

149. Iwatsuki K, Xu Z, Takata M, Iguchi M, Ohtsuka M, et al. (1999) The association of latent Epstein-Barr virus infection with hydroa vacciniforme. $\mathrm{Br} \mathrm{J}$ Dermato 140: 715-721.

150. Kil EH, DeLeo VA (2011) A survey examination of patients with hydroa vacciniforme. Cutis $88: 245-253$.
Citation: Lima M (2013) Aggressive Mature Natural Killer Cell Neoplasms: From Ebv-Infection to Disease Etiopathogeny. J Blood Disorders Transf 5 193. doi: $10.4172 / 2155-9864.1000193$ 